\title{
COMPLETE LIST \\ OF THE MANCHESTER UNIVERSITY PRESS \\ STUDIES IN IMPERIALISM SERIES, \\ 1985-2013
}

1984 John M. MacKenzie, Propaganda and empire

1986 John M. MacKenzie (ed.), Imperialism and popular culture

1988 David Arnold (ed.), Imperial medicine and indigenous societies

1988 J.W.M. Hichberger, Images of the army: the military in British art, 1815-1914

1988 Paul Greenhalgh, Ephemeral vistas: exhibitions and expositions universelles

1988 John M. MacKenzie, The empire of nature: hunting, conservation and British imperialism

1988 J.A. Mangan (ed.), 'Benefits bestowed': education and British imperialism

1988 W.J. Reader, 'At duty's call': a study in obsolete patriotism

1989 Jeffrey Richards (ed.), Imperialism and juvenile literature

1990 Robert M. Bliss, Revolution and empire

1990 Stephen Constantine (ed.), Emigrants and empire

1990 Ronald Hyam, Empire and sexuality

1990 John M. MacKenzie (ed.), Imperialism and the natural world

1990 J.A. Mangan (ed.), Making imperial mentalities

1990 David E. Omissi, Air power and colonial control

1990 Robin W. Winks and James R. Rush (eds), Asia in western fiction

1991 J.S. Bratton et al, Acts of supremacy: The British empire and the stage, 1890-1930

1991 David M. Anderson and David Killingray (eds), Policing the empire

1992 John M. MacKenzie (ed.), Popular imperialism and the military

1992 David M. Anderson and David Killingray (eds), Policing and decolonisation

1994 Robert H. MacDonald, The language of empire

1994 Tim Youngs, Travellers in Africa

1995 Kent Fedorowich, Unfit for heroes: reconstruction and soldier settlement 


\section{STUDIES IN IMPERIALISM}

1995 Mrinalina Sinha, Colonial masculinity

1996 Kathryn Castle, Britannia's children: reading colonialism through children's books

1996 Keith Jeffery (ed.), 'An Irish empire'? Aspects of Ireland and the British empire

1997 Andrew Cunningham and Bridie Andrews (eds), Western medicine as contested knowledge

1998 Clare Midgley (ed.), Gender and imperialism

1998 Gordon T Stewart, Jute and empire

1998 Brian Stoddart \& Keith A P Sandison (eds), The imperial game

1998 Martin Thomas, The French empire at war 1940-45

1998 Marjory Harper, Emigration from Scotland between the wars

1999 Felix Driver and David Gilbert (eds), Imperial cities

1999 Robert Bickers, Britain in China: community, culture, colonialism 1900-49

1999 David Killingray and David Omissi (eds), Guardians of empire

2000 Donal Lowry (ed.), The Boer War reappraised

2000 Robert Bickers \& Christian Henriot (eds), New Frontiers: Imperialism's new communities in East Asia, 1842-1953

2000 Saul Dubow (ed.), Science and society in South Africa

2000 Rob David, The Arctic in the British imagination, 1818-1914

2001 Lynette Russell (ed.), Colonial frontiers: Indigenous-European encounters in settler societies

2001 Stuart Ward (ed.), British culture and the end of empire

2001 Diane Kirkby and Catharine Coleborne (eds), Law, history and colonialism: the reach of empire

2001 Jeffrey Richards, Imperialism and music: Britain 1876-1953

2002 Mary A. Procida, Married to the Empire: Gender, Politics and Imperialism in India, 1883-1947

2002 Katie Pickles, Female imperialism and national identity

2003 Anandi Ramamurthy, Imperial persuaders: images of Africa and Asia in British advertising

2003 Evans, Grimshaw, Philips and Swain, Equal subjects, unequal rights: Indigenous peoples in British settler colonies

2003 Chandrika Kaul, Reporting the Raj: the British press and India, c. $1880-1920$

2003 Bill Schwarz (ed.), West Indian intellectuals in Britain

2003 John Marriott, The other empire: Metropolis, India and progress in the colonial Imagination

2004 Dana Arnold (ed.), Cultural identities and the aesthetics of Britishness

2004 Satadru Sen, Migrant races: Empire, identity and K.S. Ranjitsinhii

2004 Edward M. Spiers, The Victorian soldier in Africa 
2004 Heather Streets, Martial races and masculinity in the British Army, 1857-1914

2005 Marjory Harper (ed.), Emigrant homecomings: the return movement of migrants 1600-2000

2005 Brenda M. King, Silk and empire

2005 Martin Thomas, The French empire between the wars

2005 Zöe Laidlaw, Colonial connections 1815-45: Patronage, the information revolution and colonial government

2005 Douglas Hamilton, Scotland, the Caribbean and the Atlantic World, 1750-1820

2006 Diane Robinson-Dunn, The harem, slavery, and British imperial culture

2006 Annie Coombes (ed.), Rethinking settler colonialism

2006 Richard Phillips, Sex, politics and empire: a postcolonial geography

2006 Freda Harcourt, Flagships of imperialism

2006 Georgina Sinclair, At the end of the line: colonial police forces and the imperial endgame, 1948-80

2006 Daniel Gorman, Imperial citizenship: empire and the question of belonging

2007 Chloe Campbell, Race and empire: eugenics in colonial Kenya

2007 Cecily Jones, Engendering Whiteness: White women and colonialism in Barbados and North Carolina, 1627-1865

2007 Helen Tilley (ed.) with Robert J. Gordon, Ordering Africa: anthropology, European imperialism, and the politics of knowledge

2007 John M. MacKenzie with Nigel R. Dalziel, The Scots in South Africa: ethnicity, identity, gender and race

2007 Kirsty Reid, Gender, crime and empire: convicts, settlers and the state in early Colonial Australia

2008 Kate O'Malley, Ireland, India and empire: Indo-Irish radical connections, 1919-64

2008 David Hardiman, Missionaries and their medicine: a Christian modernity for tribal India

2008 A. Martin Wainwright, 'The better class' of Indians: Social rank, imperial identity and South Asians in Britain 1858-1914

2008 S. Haggerty, A. Webster \& N. White (eds), The empire in one city? Liverpool's inconvenient imperial past

2009 Mary Conley, From Jack Tar to Union Jack: representing naval manhood in the British Empire, 1870-1918

2009 Andrekos Varnava, British imperialism in Cyprus, 1878-1915: the inconsequential possession

2009 John M. MacKenzie, Museums and empire: natural history, human cultures and colonial identities

2009 Carol Polsgrove, Ending British rule in Africa: writers in a common cause

2009 Lucy Chester, Borders and conflict in South Asia: the Radcliffe boundary commission and the partition of Punjab 


\section{STUDIES IN IMPERIALISM}

2009 Emma Robertson, Chocolate, women and empire: a social and cultural history

2009 Gordon Pirie, Air Empire: British imperial civil aviation 1919-39

2010 John McAleer, Representing Africa: landscape, exploration and empire in southern Africa, 1780-1870

2010 Shurlee Swain and Margot Hillel, Child, nation, race and empire

2010 Mary Chamberlain, Empire and nation-building in the Caribbean: Barbados 1937-66

2010 Pratik Chakrabarti, Materials and medicine: trade, conquest and therapeutics in the eighteenth century

2011 John M. MacKenzie (ed.), European empires and the people

2011 Angela McCarthy, Scottishness and Irishness in New Zealand since 1840

2011 Neville Kirk, Labour and the politics of Empire

2011 Frances Steel, Oceania under steam: Sea transport and the cultures of colonialism

2011 Lindsey Proudfoot and Dianne Hall, Imperial spaces: placing the Irish and Scots in colonial Australia

2011 Huw Bowen (ed.), Wales and the British overseas empire

2011 Patrick D. O'Leary, Servants of the empire: the Irish in Punjab, 1881-1921

2011 Michael D Leigh, Conflict, politics and proselytism: Methodist missionaries in colonial and postcolonial Upper Burma, 1887-1966

2011 Helen Cowie, Conquering nature in Spain and its empire

2012 Giordano Nanni, The colonisation of time: ritual, routine and resistance in the British empire

2012 Gordon Pirie, Culture and caricatures of British imperial aviation: passengers, pilots, publicity

2012 Sarah Longair and John McAleer (eds), Curating empire: Museums and the British imperial experience

2012 Brad Beaven, Visions of empire: patriotism, popular culture and the city

2012 Andrew J May, Welsh missionaries and British imperialism

2012 Dianne Lawrence, Genteel women: Empire and domestic material culture, 1840-1910

2013 Will Jackson, Madness and marginality: the lives of Kenya's White insane

2013 Christopher Prior, Exporting empire: Africa, colonial officials and the construction of the British imperial state, c. 1900-39

2013 Catherine Ladds, Empire careers: working for the Chinese Customs Service, 1854-1949

2013 Kent Fedorowich and Andrew S. Thompson (eds), Empire, migration and identity in the British World

2013 Tamson Pietsch, Empire of scholars: universities, networks and the British academic world, 1850-1939 
2013 Doug Lorimer, Science, race relations, and resistance: Britain, 1870-1914

2013 Berny Sèbe, Heroic imperialists in Africa: the promotion of British and French colonial heroes, 1870-1939

2013 Emily Manktelow, Missionary families: race, gender and generation on the spiritual frontier

2013 Andrew S. Thompson (ed.), Writing imperial histories 
Andrew S. Thompson - 9781526112552

Downloaded from manchesterhive.com at $04 / 26 / 2023$ 09:44: 04 AM via free access 